\title{
Artikkeli
}

\section{Kiertotalouden kehykset: Vertailussa viranomaisviestintä ja kansalaisten määritelmät}

\begin{abstract}
Kiertotaloudesta puhutaan mediassa, viranomaisviestinnässä ja poliittisessa keskustelussa paljon. Esimerkiksi Suomen hallitusohjelmassa sana kiertotalous esiintyy 30 kertaa, monen eri hallinnonalan yhteydessä, monenlaisissa kehyksissä. Tarkastelemme tässä artikkelissa, miten viranomaisviestinnän ja strategiapuheen kohdeyleisö eli suomalaiset selittävät ja kehystävät tämän Suomen tulevaisuuden keskeiseksi määrittäjäksi nostetun sanan. Vertaamme pääasiassa yliopisto-opiskelijoista koostuvan vastaajajoukon määritelmiä viranomaisviestinnässä ja tiedeyhteisössä vakiintuneisiin merkityksiin ja pohdimme kiertotalous-sanan mahdollisia ongelmia viestinnän ydinsanana. Teoreettinen näkökulmamme on pääosin kehysanalyyttinen, ja hyödynnämme tässä yhteydessä myös kehyssemanttista teoriaa. Viranomaiset ja tiedeyhteisö viittaavat kiertotaloudella yleensä kokonaan uuteen talousmalliin, jossa keskeistä on uusien liiketoimintamahdollisuuksien löytäminen ja sitä kautta kansantalouden kasvu ja kilpailukyvyn turvaaminen myös tulevaisuudessa. Kyselyymme vastanneiden tulkinnoissa kiertotalous samastuu pitkälti kierrätykseen, joka on lopulta melko kapea kiertotalouden osa-alue. Käy myös ilmi, että huomattava osa vastaajista ei osaa sijoittaa kiertotaloutta mihinkään viranomaisviestinnän näkökulmasta relevantteihin kehyksiin.
\end{abstract}

AVAINSANAT: kiertotalous, kehysanalyysi, kehyssemantiikka, viranomaisviestintä

Y mpäristötietoisuus, kestävä kehitys ja luontoa säästävät talouskasvun mahdollisuudet ovat nousseet viime vuosikymmeninä vahvasti esiin yhteiskunnallisessa keskustelussa. Yksi tässä keskustelussa usein esiintyvä käsite on kiertotalous. Käsitteenä kiertotalous on laaja ja kattaa suuren joukon periaatteita ja toimintamalleja. Eri yhteyksissä se saa myös hieman erilaisia merkityssisältöjä ja painotuksia, ja määritelmien taustalla on erilaisia näkökulmia ja intressejä (ks. Murray ym. 2017, 370-372). Viranomaiset, poliitikot ja media siinä missä kuluttajaa puhuttelevat yrityksetkin valikoivat käsitteen laajasta merkitysalasta kulloinkin tarkoituksenmukaisia 
elementtejä ja saattavat siten kehystää kiertotalouden hyvin moninaisin tavoin (ks. Karvonen 2000, 82).

Tässä artikkelissa tutkitaan, miten kuluttaja-kielenpuhuja-kansalaiset tunnistavat, määrittelevät ja kehystävät kyselyssämme sanan kiertotalous, ja verrataan näitä määritelmiä tiedeyhteisössä ja viranomaisviestinnässä vakiintuneisiin ja siten yhteiskunnan toimintaa, kuten politiikkaa ja lainsäädäntöä, ohjaaviin merkityksiin. Tarkastelun teoreettiset avainkäsitteet ovat kehys ja kehystäminen, jolla viitataan tapaan määritellä ja kontekstoida eli valita kielellinen ja siten myös yhteiskunnallinen viitekehys jollekin sanalle, käsitteelle tai ilmiölle ja sitä kautta tuottaa tälle merkityksiä (ks. Karvonen 2000, 78-80; Watson 2016, 158). Toisaalta vakiintuneet kehykset ovat myös odotuksenmukaisia rakenteita, joita viestintätilanteen osapuolet hyödyntävät ilmiöiden käsittelyssä. Kehystämisen ohella tarkastelemme myös sitä, missä määrin tutkimukseemme vastanneet ylipäänsä tunnistavat sanan kiertotalous, sekä muita sanan selittämisessä esiin nousevia seikkoja. Kaikki huomiomme eivät siis suoraan nivoudu kehystämisen käsitteeseen vaan myös esimerkiksi vastauksissa esiin tulevaan varmuuden tai epävarmuuden osoittamiseen, arvottaviin ilmauksiin tai vastauksissa hahmottuviin assosiaatioketjuihin.

Edellä mainittu kontekstointi ja kontekstin käsite ymmärretään tässä artikkelissa laajasti. Kyse on tavoista, joilla selitettävä käsite tai ilmiö paikannetaan yhteiskuntaan: mihin se liittyy, missä se tapahtuu ja ketkä sitä tekevät. Kontekstin rakentaminen tapahtuu tämän artikkelin aineistossa aina kielellisesti, mutta lähestymistavat vaihtelevat: konteksti voidaan rakentaa tuottamalla käsiteverkostoa, johon selitettävä käsite sijoitetaan, tai viittaamalla konkreettisiin toimintoihin, tilanteisiin tai vaikkapa ideologisiin tai historiallisiin kiinnekohtiin. Yksi erityisen kiinnostava aspekti tarkastelussamme onkin se, millaisia selittämis- ja kehystysstrategioita vastaajat valitsevat ja millaisista elementeistä he annetun käsitteen ja ilmiön kontekstin rakentavat. Kontekstin käsite on tässä artikkelissa laaja siitäkin syystä, että tarkastelu on pitkälti aineistolähtöistä eli selvitämme ilman ennakko-oletuksia, millaisia kehystämisen ja selittämisen tapoja aineistosta nousee. Kontekstin rakentamiseen liittyy toisinaan myös puhujan oman position ja etäisyyden määrittely: olenko minä osa tätä ilmiötä vai sanoudunko siitä irti ja miten ylipäänsä suhtaudun siihen. (Kontekstin laajasta määrittelystä ks. esim. Halliday \& Matthiesen 2014.)

Median ja viestinnän tutkimuksessa kehyksen käsitettä on kenties tyypillisimmin käytetty median tuottamiin ja toisintamiin kontekstointitapoihin viitaten, joskin käsitteen teoreettiset juuret juontavat niin moniaalle, että se on taipunut tälläkin alalla työkaluksi monenlaisiin tutkimusasetelmiin (ks. Karvonen 2000; Matthes 2009, 349-352). Tässä artikkelissa kehyksiä tarkastellaan laajassa mielessä viitaten sekä viestinnässä tehtyihin valintoihin että kyselyyn osallistuneiden vastauksissa hahmottuviin tulkintamalleihin (ks. Karvonen 2000, 81-82). Ymmärrämme joka tapauksessa kaikissa tilanteissa kehyksen tekstistä luettavana kontekstointina ja näkökulmavalintana (ks. Entman 2007, 164-165; Väliverronen 2007) emmekä esimerkiksi tekstin kirjoittajan mentaalisen ulottuvuuden oliona, oli kehystäjä sitten media, viranomainen tai yksittäinen kansalainen (ks. Edwards 1997, 288). Toisaalta käsittelyä ohjaavat pit- 
kälti myös käytännölliset viestinnän kysymykset. Pohdimme muun muassa kiertotaloussanan käyttökelpoisuutta ja mahdollisia ongelmia viranomaisviestinnässä ja kuluttajaviestinnässä.

Havainnollistavan esimerkin kehysten moninaisuudesta ja eräänlaisesta kehystyskilpailusta ympäristö- ja vastuullisuusteemojen yhteydessä tarjoaa vaateyhtiö H\&M:n lanseeraaman vaatteiden vuokrauspalvelun käsittely mediassa syksyllä 2019 (Kauppalehti.fi 23.8.2019; Suomen Kuvalehti 29.8.2019). Talousmedia kehysti tapahtuman pragmaattisesti yhtiön palvelutarjooman laajentamiseksi. Yhtiö taas nosti ohelle laajemman näkökulman ja tiedotti kyseessä olevan askel kohti "muodin kiertotaloutta", mikä kehysti uuden toiminnon osaksi liiketoiminnan strategista muutosta. Suomen Kuvalehden haastattelema yritysvastuuasiantuntija taas nimitti H\&M:n toimintaa viherpesuksi kehystäen sen siis imagopoliittiseksi manööveriksi. Yritysvastuuasiantuntijan esittämän kriittisen näkemyksen mukaan vuokrauspalvelulla on yhtiön liiketoiminnalle korkeintaan marginaalinen merkitys, joten kyse ei ole strategisesta linjavedosta vaan yksinomaan symbolisesta eleestä. Lukijalle ja kuluttajalle tällaisessa tilanteessa on näin ollen tarjolla useita kehyksiä, joita hän voi itse ottaa käyttöön ja sillä tavoin uusintaa omassa viestinnässään.

Kiertotalouden kaltaisten laajojen käsitteiden yhteydessä tällainen yksittäinen, havainnollinen ja mieleen jäävä tapaus saattaa ohjata lukijan mielikuvia vahvastikin. Monitulkintaisten käsitteiden samoin kuin eri tavoin kiistanalaisten ilmiöiden yhteydessä käydään usein myös määrittelykamppailua ja käytössä voi samaan aikaan olla useita kilpailevia kehyksiä (ks. esim. Rönkä 2011). Jotkut kehyksistä vakiintuvat ja luonnollistuvat, toiset unohdetaan tai todetaan ajan myötä merkityksettömiksi kohteen kannalta (ks. Tromble \& Meffert 2016). Vaikuttaa siltä, että kiertotalouden suhteen eletään jonkinlaisessa käymistilassa, osin epätiedonkin ajassa, ja on kiinnostava havainnoida, millaiseksi käsitteen käyttö ja merkitys ajan saatossa muodostuvat.

\section{Kiertotalous strategiatekstien ydinsanana ja strategisena tavoitteena}

Viime vuosina kiertotalouden edistäminen on noussut valtioiden ja kansainvälisten toimijoiden, kuten EU:n, YK:n ja OECD:n, politiikan agendalle ja julkilausutuksi strategiseksi tavoitteeksi (Reike ym. 2018, 246). Suomen hallitusohjelmassa (Osallistava ja osaava Suomi 2019) kiertotalous mainitaan 30 kertaa ja se tulee esiin keskeisenä käsitteenä monissa tavoitteissa: ympäristöpolitiikan lisäksi muiden muassa koulutuksen ja tutkimuksen, kansainvälisen yhteistyön, ulkomaankaupan ja asuntotuotannon yhteydessä. Hallitusohjelmassa Suomi määritellään kiertotalouden edelläkävijäksi ja tämän position edelleen vahvistaminen keskeiseksi kansalliseksi tavoitteeksi.

Siksi on kiinnostavaa tarkastella Suomen kansalaisten ymmärrystä ja määritelmiä eli muun muassa heidän omaksumiaan kehyksiä tämän keskeisen käsitteen kohdalla. Viranomaisviestinnän onnistumisen sekä yleisesti ottaen demokratian, osallistumisen ja osallisuuden kannalta on hyödyllistä, että kieli ja termistö ovat läpi yhteiskunnan yhtei- 
siä, ymmärrettyjä ja jaettuja. Esittelemme seuraavassa muutamia keskeisiä lähteitä, joiden perusteella osoitamme kiertotalouden vakiintuneet merkityselementit ja tarkastelemme niiden esiintymistä kyselyymme osallistuneiden kansalaisten vastauksissa.

Joskus ratkaisut ovat kiertotalouden määritelmän mukaisia vain tietyiltä osin (ks. esim. jakamistalous jäljempänä), ja eri yhteyksissä painotetaan hieman eri aspekteja. Kiertotalous-sanan keskeisimmät merkityselementit ovat kuitenkin jokseenkin vakiintuneita. Esimerkiksi Sitra (2016) määrittelee kiertotalouden "talousmalliksi, jossa ei tuoteta jatkuvasti lisää tavaroita, vaan kulutus perustuu omistamisen sijaan palveluiden käyttämiseen: jakamiseen, vuokraamiseen ja kierrättämiseen. Siinä materiaaleihin sitoutunut arvo säilyy mahdollisimman pitkään yhteiskunnassa. Kiertotaloudessa talouskasvu ei ole riippuvainen luonnonvarojen kulutuksesta." Sitra toimii tiiviissä yhteistyössä Suomen hallituksen kanssa kiertotalouden tutkimiseksi ja edistämiseksi, joten edellä mainitussa lainauksessa tulee tiiviisti ilmaistuksi se, mitä kiertotaloudella lähtökohtaisesti tarkoitetaan hallitusohjelmassa ja muussa virallisen Suomen viestinnässä. Monesti toki sana saa käyttökontekstissaan myös kapeamman tai jollakin tavoin painottuneen kehystyksen.

Kirchherr ja muut (2017) sekä Merli ja muut (2018) ovat analysoineet laajoissa kirjallisuuskatsauksissaan tieteellisissä julkaisuissa esitettyjä kiertotalouden määritelmiä. Suurta osaa kiertotaloustutkimuksista luonnehtii heidän mukaansa soveltava ja implementoiva näkökulma, jossa keskiössä on tuotantoprosessien ja paikoin myös uusien liiketoimintamallien kehittäminen kestävällä, neitseellisiä raaka-aineita säästävällä, jätettä mahdollisimman vähän tuottavalla ja ylipäänsä ympäristöä mahdollisimman vähän kuormittavalla tavalla. Resurssien ja raaka-aineiden arvon säilyttäminen tulee myös esiin keskeisenä periaatteena (ks. myös Reike ym. 2018, 247), samoin tuotannon sivuvirtojen mahdollisimman tehokas hyödyntäminen (ks. myös Homrich ym. 2017, 529-532). Monissa määritelmissä mainitaan keskeisenä tekijänä eronteko lineaaritalouteen, jossa käytetään runsaasti luonnonvaroja, raaka-aineita ja energiaa sekä tuotetaan runsaasti jätettä (ns. take-make-dispose-malli vrt. closed loops -malli) (ks. myös esim. Euroopan parlamentti 2018). Usein mainittu termi on irtikytkentä, jolla tässä yhteydessä tarkoitetaan talouskasvun erottamista luonnonvarojen liikakäytöstä.

Määritelmissä korostetaan usein nimenomaan kokonaisvaltaisen strategisen ajattelun merkitystä: kiertotalous ei ole pelkkää jätteiden minimointia ja kierrätystä vaan talousmalli, jossa harjoitetaan liiketaloudellisesti kannattavaa toimintaa (ks. Genovese ym. 2017, 344-345; Sitra 2016). Tästä näkökulmasta usein esiin tuotu argumentti on uudet markkinat, joita kiertotalouteen siirtyminen loisi (Nylén 2019, 14-15). Jotkin nykyisistä tuotannonaloista kenties supistuisivat, muuttaisivat muotoaan tai lakkaisivat kokonaan, mutta niiden ohelle ja tilalle syntyisi uusia talouden alueita. Toisaalta, kuten Merli ja muut $(2018,717)$ huomauttavat, kiertotalouden akateemisen tutkimuksen juuret ovat ympäristötieteissä, mikä on vaikuttanut ja vaikuttaa edelleen termistöön ja painotuksiin sekä mielikuviin ja kehystyksiin niin tiedeyhteisön sisällä kuin laajemman yleisön keskuudessakin.

Kielellisenä konstruktiona kiertotalous-sanaa on myös kritisoitu. Nuutinen (2014) tuo esiin sanan semanttisen väljyyden ja monitulkintaisuuden; esimerkiksi kiertää- 
verbin merkitys 'välttää, väistää' mahdollistaa veronkiertoassosiaatioiden kaltaiset harhaanjohtavat mielikuvat. Myös ajoittainen käyttötapojen epäsystemaattisuus on aiheuttanut hämmennystä (Kirchherr ym. 2017, 221). Tieteenalojen välinen keskustelu on ollut hankalaa, koska käsitettä on määritelty ja käytetty eri tavoin (Sauvé ym. 2016, 50; Korhonen ym. 2018, 39; Reike ym. 2018, 246-247). Väljyys on mahdollistanut myös käsitteen merkityksen laajentumisen vuosien varrella, mikä osaltaan lisää kehystämiseen liittyvän yhteisymmärryksen haasteellisuutta. Puhutaan kerroksisuudesta eli laajenevasta semanttisesta sisällöstä, jota kiertotaloudelle on kertynyt monialaisen keskustelun myötä. (Mahanty ym. 2019, 251-252; ks. myös Merli ym. 2018, 718.)

Myös puutteellista määrittelyä ja rajaamista suhteessa lähikäsitteisiin on kritisoitu: esimerkiksi kiertotalouden suhde kestävään kehitykseen on koettu epäselväksi ja siten koko tämän alueen termistö hankalaksi omaksua ja käyttää (rajanvedosta ks. Geissdoerfer ym. 2017). Kestävä kehitys ja kiertotalous ovat monin tavoin läheisiä, ideologisesti yhteensopivia; voidaan sanoa, että kestävä kehitys on kiertotalouden tavoite tai toimintaperiaate. Tällaiset yhteydet ovat kuitenkin usein jääneet kansalaisille hämäriksi.

Kiertotalouspuhetta saattavat rasittaa myös eräät historiallis-diskursiiviset tai assosiatiiviset kytkökset, kuten ajatus yritysten ympäristö- ja vastuullisuusviestinnästä niin sanottuna viherpesuna (Torelli ym. 2019, 407-408) sekä kierrätystuotteiden laatuun ja saatavuuteen liittyvä epäluulo (ks. Singh \& Ordonez 2016, 349). Myös ympäristövastuuseen usein kytkeytyvän muutospuheen imperatiivinen sävy - jostakin on luovuttava ja totunnaista elämäntapaa on joiltain osin arvioitava uudelleen - voi herättää vastustusta ja haluttomuutta perehtyä asiaan. Poliittisessa keskustelussa kielteisiin kantoihin saattavat taas vaikuttaa sidokset viiteryhmiin, joiden agendalla voi olla kestävän kehityksen kanssa ristiriitaisia tavoitteita (ks. Wolsko ym. 2016). Aikomusten ja tekojen välillä voi olla myös kynnyksiä; esimerkiksi suomalaisten vahvasti positiivisten ympäristönsuojeluasenteiden muuntumisessa käytännön kulutuspäätöksiksi on havaittu kitkaa (ks. Hirvonen \& Vanhatalo 2018, 73-74; Sitra \& Kantar TNS 2017). Keskustelu on siis monin tavoin jännitteistä, ja onkin kiinnostava tarkastella, näkyvätkö tällaiset jännitteet tämän tutkimuksen aineistossa.

\section{Tutkimuskysymykset ja tutkimuksen tavoitteet}

Kysyimme 226 suomalaiselta, miten he ymmärtävät ja määrittelevät sanan kiertotalous tai mitä heille ylipäänsä tulee siitä mieleen. Tulosten perusteella pyrimme vastaamaan seuraaviin kysymyksiin:

1. Kuinka hyvin kyselyyn vastaajien kiertotalous-määritelmät vastaavat tiedeyhteisössä ja viranomaisten viestinnässä vakiintuneita määritelmiä? Miltä osin ne erityisesti eroavat toisistaan?

2. Millaisia kehyksiä vastaajat käyttävät ja tuottavat määritellessään kiertotaloutta terminä ja toimintana?

3. Millaisia viestinnällisiä ongelmia kiertotalous-sanaan mahdollisesti liittyy? 
Tarkoituksemme on paitsi analysoida sanalle annettuja määritelmiä ja kehyksiä myös pohtia kielellisiä ja diskursiivisia rakenteita, assosiaatioita ja muita tekijöitä erilaisten, etenkin vakiintuneista poikkeavien, määritelmien ja kehysten taustalla.

Käytämme analyyttisena pääkäsitteenä kehystä ja kehystämistä, joskin tarkastelemme kyselyaineiston valossa myös muun muassa kiertotalouden yleistä tunnettuutta ja kiertotalouteen asennoitumista. Tarkastelun kuitenkin läpäisee kehystämisen idea siinä mielessä, että kaikessa on jollakin tavoin kyse verrattain uuden, semanttisesti laajan ja monikäyttöisen käsitteen paikantamisesta yhteiskunnallisiin, kielellisiin ja paikoin esimerkiksi poliittisiin kehyksiin. Yhtä lailla kiinnostavaa on sekin, jos vastaaja ei löydä sanalle minkäänlaista luontevaa kehystä.

Käsittelyssä on myös käytännönläheinen ulottuvuus, sillä pohdimme kiertotaloussanan käyttökelpoisuutta viranomaisviestinnässä ja julkisessa keskustelussa sekä pohdimme mahdollisia sanaan liittyviä ongelmia.

\section{Kehys teoreettisena työkaluna}

Kehys on muiden muassa kieli-, viestintä-, media- ja sosiaalitieteiden alalla laajalti käytetty käsite (Fillmore \& Baker 2009, 315-317; Gamerschlag ym. 2014, 4-7; Goffmann 1974; Karvonen 2000, 83; Matthes 2009, 349-352). Yhteistä eri tutkimussuuntauksille on tarkastella ilmiötä esitetyissä kehyksissä, siis kontekstien, käyttöyhteyksien ja erilaisten semanttisten suhdeverkostojen kautta. Kehystyksillä on suuri merkitys ensinnäkin siinä, millaisia retorisia asetelmia ja mielikuvia julkisessa keskustelussa tuotetaan ja toiseksi siinä, millaisia tulkintoja ilmiöt ja ilmaukset saavat kieliyhteisössä tai yhteiskunnassa pidemmän ajan kuluessa. (Watson 2016, 182-184.) Yhdistämme tässä tutkimuksessa kehysanalyyttistä näkökulmaa myös kehyssemanttiseen teoriaan (tällaisesta asetelmasta ks. esim. Pentzold ym. 2016).

Kehysteorian laajuutta kuvaa muun muassa puhe sisäisistä ja ulkoisista kehyksistä, toisin sanoen kehyksellä voidaan viitata niin puhujan artikuloimaan kehykseen kuin vastaanottajan kognitiiviseen tulkinnan työkaluun (ks. Entman 2004, 15; Tromble \& Meffert 2016, 5082). Tässä artikkelissa kognitiivisen kehyksen käsite ei ole niinkään relevantti, sillä keskitymme teksteissä aktivoituihin kehyksiin emmekä tee oletuksia kehysten valinnan taustalla mahdollisesti vaikuttavista kognitiivisista tiloista. Kehykset ovat näkökulmastamme aina tekstuaalisia valintoja eli tapoja esittää, selittää ja kontekstoida ilmiöitä. Emme siis pidä esimerkiksi tämän tutkimuksen vastaajien tuottamia kehyksiä eri ulottuvuuden ilmiöinä kuin viranomaisten ja median tuottamia kehyksiä. Kehystäjästä riippumatta kyse on aina kehysten käyttöönotosta, hyödyntämisestä ja uusintamisesta.

Konkreettisesti kehykset aktivoidaan tekstissä useimmiten tiettyjä sanoja tai käsitteitä käyttämällä (Fillmore 1982, 112; 1985, 225). Kohdeilmiö sijoitetaan siis semanttiseen verkostoon, joka on puhujan tai puhetilanteen kannalta tavalla tai toisella tarkoituksenmukainen (ks. Fillmore \& Baker 2009, 314; Malrieu 1999, 77-78; Coulson 2015, 167-169; Diederich 2015, 82-83). Kehykseen kuuluu käsiteverkoston lisäksi kulttuu- 
rinen konteksti ja sitä kautta viestintätilanteen osallisten jakama taustaymmärrys, joka liittyy tilanteisiin, puhujapositioihin ja diskursseihin (ks. Niemi 2013, 205). Diskurssien, kehysten ja semanttisten nyanssien tuntemus on tietenkin myös olennainen retorinen resurssi, jota hyödyntämällä kehystys ja sitä kautta huomion ohjaaminen voidaan tehdä hienovaraisesti.

Kuulijalla ei ole aina riittävää kehystietoa uuden sanan tai käsitteen omaksumiseksi. Käyttökelpoiset kehykset voivat olla joko yleissivistykseen pohjaavia tai spesifimpää asiantuntijatietoa edellyttäviä. (Ks. Fillmore \& Baker 2009, 314-315.) Kiertotalous-sanan laajuus ja kerroksellisuus ovat tämän artikkelin aineiston analyysin kannalta huomionarvoisia tässäkin katsannossa: perustavanlaatuisella tasolla, olennaisimpien periaatteidensa osalta, käsite on suhteellisen yksinkertainen. Kuitenkin edettäessä hienosyisempään semanttiseen analyysiin kohdataan kiistanalaisia rajanvetoja ja terminologiaa, joka sijoittuu pikemmin erityisalojen kielen kuin yleissivistyneen arkipuheen alueelle.

Ilmiöitä asetetaan kehyksiin myös arvottavassa mielessä tai moraalisen arvioinnin näkökulmasta (Coulson 2001, 227-228). Tämä näkökulma korostuu erityisesti kriittistä kehysanalyysia hyödyntävissä tutkimuksissa, joissa tarkastellaan tapoja kehystää yhteiskunnallisia ilmiöitä. Julkisessa keskustelussa joillakin puhujilla on enemmän vaikutusvaltaa kuin toisilla ja heidän kehystyksensä vakiintuvat todennäköisemmin ilmiön tarkastelun näkökulmina. (Ks. esim. Verloo \& Lombardo 2007, 40.) Tässä artikkelissa ei ole mahdollista suoranaisesti tarkastella tällaisia valtakysymyksiä, mutta näkökulma on sinänsä relevantti myös kiertotalouden kohdalla, sillä aihetta kehystetään julkisessa keskustelussakin vaihtelevin tavoin. Ympäristöja vastuullisuuskysymykset ovat tyypillisesti vastakkaisia intressiryhmiä aktivoivia puheenaiheita, joiden yhteydessä kiistellään usein myös erilaisten kehystystapojen legitimiteetistä (Joutsenvirta 2006; Väliverronen 1996). Tässä mielessä kiertotalouden asemoituminen suomalaiseen mediamaisemaan ja julkiseen keskusteluun on lähitulevaisuudessakin kiinnostava tutkimuskohde.

Kehyssemantiikan tutkimuksessa kutsutaan kehyselementeiksi (frame elements) sanoja ja käsitteitä, jotka ovat tietylle kehykselle olennaisia tai välttämättömiä. Näiden lisäksi kaikkiin kehyksiin liittyy aina valinnaisia elementtejä. Moni kehyselementti voi olla osa useampaa kehystä ja siten linkittää kehyksiä toisiinsa. (Fillmore \& Baker 2009, 329-330; ks. myös Gawron 2019, 64-65.) Tämä avaa kiinnostavia näkökulmia myös kiertotalouden tarkasteluun. Vastuullisuus-kehyksen lisäksi kiertotaloutta voidaan tarkastella vaikkapa poliittisena projektina, talousmallina tai teknisessä kehyksessä, teknologian ja prosessien kehittämisen ongelmana. Kaikki nämä kehykset ohjaavat kiertotalouspuhetta omaan suuntaansa ja näin kiertotalouskeskustelu saa useita ulottuvuuksia, jotka paikoin kytkeytyvät toisiinsa mutta ovat monin paikoin myös kokonaan omia keskustelujaan omine ongelmanasetteluineen.

Kiertotalouskeskustelussa esiintyy myös edellä mainitun kaltaisia linkkikäsitteitä. Kiertotalouden piiriin luetaan tietyin ehdoin esimerkiksi biotalouden tai jakamistalouden kaltaisia aloja tai toimintamalleja, jotka eivät kuitenkaan kaikissa 
muodoissaan edusta kiertotaloutta. Tällä tavoin ne toimivat kiertotalous-kehyksen vankkoina elementteinä, mutta joiltakin osin kuuluvat pikemmin johonkin toiseen kehykseen ja ikään kuin rakentavat sukulaissuhteita kehysten välille Tällaisten linkitysten kautta kiertotalouskeskustelu voi saada hyvin erilaisia painotuksia. Tässä medialla on epäilemättä huomattava rooli: Rakennetaanko vaikkapa kiertotalouden periaatteita noudattavien toimijoiden, innovaatioiden ja tuotteiden välille linkkejä yhtenäistä käsitteistöä käyttäen - ja alan toimijoiden usein symbioottisia suhteita osoittaen - vai jäävätkö tapaukset irrallisiksi, erillisiin kehyksiin, joita kiertotalouden kaltainen kattokäsite ei nivo yhteen?

Kehystyksen yhteydessä puhutaan usein myös narratiiveista, joita erityisesti mediassa tuotetaan ja vahvistetaan: omaksumme käsityksiä ilmiöiden välisistä syyseuraussuhteista sekä historiallisista kehityskuluista ja käsittelemme uutta informaatiota tällaisten kontekstien valossa (esim. Stoddard \& Smith 2016; Harju \& Karvonen 2016). Blomsma ja Brennan (2017) yhdistelevät kehysanalyysia ja narratiivista analyysia tutkiessaan, miten kiertotalouden käsite ja idea kytkeytyvät laajempaan jätettä vai resurssia -keskusteluun, jota on käyty 1960-luvulta lähtien. Blomsma ja Brennnan konstruoivat tässä keskustelun pohjalta narratiivin, joka kuvaa keskustelun logiikkaa ja kulkua sekä keskustelussa luotuja skenaarioita. Tämä julkisessa keskustelussa jäsentyvä narratiivi on useiden median käyttäjien tunnistama ja siten eräänlainen kehys: informaation tulkinnan sekä ajallisen ja temaattisen kontekstoinnin väline. Voidaan ajatella, että hallitusohjelman kaltaisessa strategiatekstissä luonnostellaan eräänlaista tulevaisuuteen ulottuvaa narratiivia, globaalien haasteiden paineessa selviytyvän ja menestyvän Suomen tarinaa, jossa kiertotaloudella on keskeinen rooli. Nähtäväksi jää, saavuttaako tämä tarina tavoitellut kuulijansa eli Suomen kansalaiset.

\section{Aineisto ja metodi}

Tämän tutkimuksen pohjana toimivaan kyselyyn osallistui 226 ihmistä: Turun yliopiston kauppakorkeakoulun ja humanistisen tiedekunnan opiskelijoita, Itä-Suomen yliopiston kauppatieteiden laitoksen opiskelijoita sekä kävijöitä Turun kirjamessuilla. Valtaosa vastaajista, lähes 200, oli iältään 20-27-vuotiaita yliopisto-opiskelijoita. Kirjamessuvieraiden ikähaarukka oli laajempi, 16-65 vuotta.

Tämänlaajuisella aineistolla saavutetut tulokset eivät luonnollisestikaan ole laajasti yleistettävissä. Emme siis voi sanoa havaintojemme kertovan suoraan suomalaisten kiertotalousymmärryksestä tai -käsityksistä. Kuitenkin vastauksia analysoidessa tietyt piirteet toistuivat ja erottuivat hyvin selvästi. Tulokset ovat siis vähintään suuntaa antavia ja toimivat pohjana aihetta koskeville jatkotutkimuksille.

Kyselylomakkeessa kiertotalouden määrittelyä koskeva kysymys oli muotoiltu seuraavasti:

"Kuvaile vapaasti, mitä mielestäsi merkitsee sana kiertotalous, mihin kiertotalous liittyy tai mitä mielikuvia sana sinussa herättää?" 
Vastaukset annettiin kirjallisesti ja suhteellisen nopeasti; tavoitteenamme oli päästä käsiksi intuitiivisesti esitettyihin määritelmiin ja kehystyksiin sekä välittömiin mielleyhtymiin ja tavoittaa käsitettä koskeva välitön arkiymmärrys. Ideana oli myös tavoittaa vastaajia, jotka eivät vastaustilanteessa olleet millään tavoin erityisesti orientoituneita kiertotalousaiheeseen, toisin sanoen he eivät osallistuneet kurssille tai tapahtumaan, jonka aiheena olisi nimenomaan kiertotalous eikä heillä ollut ammatillista kytköstä aiheeseen.

Sanalle kiertotalous ei siis kyselyssä tarjottu myöskään minkäänlaista valmista kehystä tai kontekstia, vaan annettiin pelkästään sana ja mahdollisuus ilmaista vapaasti sen herättämät tulkinnat ja ajatukset. Kehyssemanttinen tutkimus olisi mahdollista toteuttaa myös siten, että tutkittava kohde tarjottaisiin tutkimushenkilöille jossakin kontekstissa: osana mediatekstiä tai muuta tekstiä, esimerkkilauseissa tai vaikkapa kuvana kyltistä, jonka taustana näkyy jotakin muuta. (Diederich 2015, 63-70; Evans 2009, 202.)

Tarkastelemme aluksi, kuinka suuri osa vastaajista selitti käsitteen samansuuntaisesti vakiintuneiden määritelmien kanssa. Poimimme artikkelin johdannossa esitellyistä kiertotalouden vakiintuneista määritelmistä yhdeksän merkityselementtiä ja tarkastelimme näiden esiintymistä. Jo tässä tulee alustavasti esiin kehysteema: mitä vastaajat valitsevat kiertotalouden laajasta merkitysalasta ja mihin määritelmät erityisesti kiinnittyvät.

Tämän jälkeen tarkastelemme vastauksia tarkemmin kehysanalyyttisesta näkökulmasta: millaisia kehyksiä vastaajat valitsivat tai tuottivat kiertotalousmääritelmissään. Mahdollisuuksien mukaan pohdimme myös, millaisia kielellisiä, diskursiivisia tai narratiivisia rakenteita vastausten taustalla saattaa vaikuttaa, erityisesti niiden vastausten kohdalla, jotka poikkeavat selkeästi vakiintuneista määritelmistä. Lopuksi pohdimme kiertotalous-sanaa ja sen mahdollisia ongelmia rakenteellisesta, semanttisesta ja viestinnällisestä näkökulmasta.

\section{Tulokset}

Ensimmäinen tutkimuskysymyksemme koski sitä, miten kyselyyn vastaajien kiertotalous-määritelmät ja -kehystykset vastaavat tiedeyhteisössä ja viranomaisten viestinnässä vakiintuneita määritelmiä. Vakiintuneista määritelmistä poimimiemme kiertotalouden yhdeksän keskeisen merkityselementin esiintyminen vastauksissa on kuvattu taulukossa 1. Esiintymäksi on tässä laskettu sekä tietyn sanan (esim. kierrätys) esiintyminen että kyseisen toiminnon kuvaaminen toisin sanoin. 
Taulukko 1. Kiertotalouden vakiintuneiden merkityselementtien esiintyminen.

\begin{tabular}{|l|l|}
\hline Merkityselementti & $\begin{array}{l}\text { Esiintymiä vastauksissa (osuus } \\
\text { kaikista vastauksista; } \mathbf{n}=226)\end{array}$ \\
\hline Kierrätys ja uudelleenkäyttö & $97(42,9 \%)$ \\
\hline Jätteen minimointi, sivuvirtojen hyödyntäminen & $15(6,6 \%)$ \\
\hline Ekologisuus & $13(5,8 \%)$ \\
\hline Kestävä kehitys & $12(5,3 \%)$ \\
\hline Raaka-aineiden pitkä kierto ja arvon säilyttäminen & $10(4,4 \%)$ \\
\hline Jakaminen, vuokraus yms. omistamisen vaihtoehtona & $9(4,0 \%)$ \\
\hline Luonnonvarojen säästäminen & $6(2,7 \%)$ \\
\hline Uudet liiketoimintamallit ja talouskasvun mahdollisuudet & $5(2,2 \%)$ \\
\hline Palvelujen kulutus materiaalisten tuotteiden sijaan & $0(0 \%)$ \\
\hline & \multicolumn{2}{|l}{} \\
\hline Vastauksia, joissa esiintyi yksi tai useampi merkityselementti & $118(52,2 \%)$ \\
\hline
\end{tabular}

Huomion kiinnittävät ääripäät: kiertotalous yhdistetään vahvasti kierrätykseen mutta hyvin heikosti liiketoimintaan. Tuottavan taloudellisen toiminnan mahdollisuudet tulivat esiin vain muutamassa vastauksessa. Palvelujen kuluttamisen ja kehittämisen painottuminen, joka on kiertotalousajattelussa tärkeä vaihtoehtoinen talouskasvun linja, ei tullut esiin lainkaan.

Kierrätyksen laaja esiintyminen on ymmärrettävää, sillä sille on löydettävissä tukea sekä leksikaalisen että ideologisen kehystiedon alueelta. Sanojen kierto ja kierrätys taustalla voi nähdä saman kiertää-kantasanan, ja toisaalta vastaajan mielessä kiertotalous ja kierrätys voivat yhdistyä, esimerkiksi mediakirjoittelun vuoksi.

Kierrätys on yksi kiertotalouden toimintamalleista mutta määrittelee lopulta kiertotaloutta melko kapeasti. Pelkkään kierrätykseen keskittyvä selitys sivuuttaa ajatuksen kiertotaloudesta talousmallina, jossa kehitetään uudenlaista liiketoimintaa ja arvontuotantoa. Tällöin kiertotalous ei välttämättä nouse kansalaisen mielessä tärkeimpien yhteiskunnallisten kehityslinjojen joukkoon, vaikka asiaan sinänsä myönteisesti suhtautuisikin.

Huomionarvoista on myös se, että kierrätys esiintyy vastauksissa hyvin vaihtelevissa kehyksissä. Osassa vastauksia vakiintunut kiertotalouskehys on selvä: kierrätyksestä puhutaan samassa merkityksessä kuin etabloituneessa kiertotalousdiskurssissa. Toisaalta osassa vastauksia jää hämärämmäksi, mitä kierrätyksellä tarkoitetaan:

(1) Kiertotalous kuvaa talouden ympäristön kierrättämistä [...]

(2) [...] tulee mieleeni systeemi, jossa erilaiset asiat kiertävät. Esimerkiksi voidaan kierrättää asioita ja käyttää niitä uudelleen muualla.

(3) Kiertotalous liittyy [...] yhteiskunnassa kiertäviin asioihin, raaka-aineisiin sekä ilmiöihin. 
Huomion kiinnittää kierrätyksen semanttinen täsmentymättömyys. Esimerkeissä 1-3 kierrätyksen kohteeksi asettuvat ylimalkaisen asioiden lisäksi muun muassa ympäristö ja ilmiöt. Vastaajien voidaan tulkita olevan oikeilla jäljillä, mutta ajatus jää varsin hämäräksi. Vastaukset herättävätkin monin kohdin jatkokysymyksen: miten kierrätys ymmärretään? Termi kierrätys on sinällään vakiintunut ja oletettavasti tunnettu läpi kieliyhteisön, mutta vaikuttaa siltä, että kaikki eivät kehystä sitä samalla tavoin. Esimerkiksi "tavaroiden kierrättäminen käyttäjältä toiselle" on melko erilaista kierrätystä kuin materiaalien keskitetty kerääminen ja uudelleenprosessointi. Ilmaus on myös epämääräinen: sen voidaan ajatella viittaavan vaikkapa tavaroiden lainaamiseen ystävien kesken tai laajamittaisempaan yhteiskäyttöön, joka on mahdollisesti kaupallisen toimijan koordinoimaa. Ensin mainittu toimintakin on toki kiertotalouden periaatteen mukaista, sillä ainakin teoriassa siinä vältetään tavaran ja jätteen tuottaminen, mutta sen nimittäminen kiertotaloudeksi venyttää sanan merkitysalaa sellaisten tapausten alueelle, jotka eivät täytä oikeastaan mitään keskeistä kriteeriä ja joissa jätteen tuottamisen välttäminenkin on lähinnä teoreettista.

Kiertotalouden liiketalouskehys eli talous sellaisessa merkityksessä, jota luonnehtivat liiketoiminnan, tuottavuuden, voitontavoittelun, arvonluonnin ja talouskasvun kaltaiset aspektit, jäi muutaman maininnan varaan. Toisaalta vastausesimerkeissä 4 ja 5 kiertotalous asetetaan kasvutalouden vaihtoehdoksi sen sijaan että se nähtäisiin tapana luoda kasvua.

(4) Tulevaisuuden toimintaa, vaihtoehto kasvutaloudelle ainakin toivottavasti. Tulee mieleen minimalismi.

(5) Kiertotalous tarkoittaa taloutta, jossa ihmiset eivät osta hyödykkeitä vaan hankkivat niitä esim. vaihtamalla hyödykkeitä keskenään.

Luonnonvarojen säästäminen näyttää assosioituvan yleiseen säästämiseen ja supistamiseen. Irtikytkentäidea eli luonnonvarojen säästämisen ja talouskasvun strateginen yhteensopivuus ei vastauksissa tule esiin. Myös esimerkissä 5 esiin tuotu vaihdanta-ajatus liitetään rahan käytön ja kulutuksen vähentämiseen ja sitä kautta talouden supistumiseen kasvun sijaan.

Jakamistaloudellisessa merkityksessä kierto tuli vastauksissa esiin verraten harvoin. Vuokraus- ja yhteiskäyttöpalveluja ei mielletä kovin vahvasti kiertotalouden toimintamalleiksi, vaikka toimintoina ne ovat monelle tuttuja. Samoin palveluiden suosiminen kulutushyödykkeinä ja esimerkiksi lahjoina materiaalisten tuotteiden sijaan lienee tuttu ajatus monelle, mutta kiertotalous-sana ei aktivoinut tällaista kehystystä yhteenkään vastaukseen. Vastausten fokus on vahvasti materiaalisessa todellisuudessa - tuotteissa, raaka-aineissa ja jätteissä - eikä palveluiden ja immateriaalisten tuotteiden näkökulma saa juuri sijaa.

Monet taulukon 1 merkityselementeistä ovat kiinteästi toisiinsa liittyviä. Näin ollen esimerkiksi mainitessaan kierrätyksen vastaaja on hyvinkin voinut ajatella myös luonnonvarojen säästymistä. Tässä olemme kuitenkin kiinnostuneita siitä, mitä vastaajille 
on ensisijaisesti tullut mieleen kiertotaloudesta ja mikä on katsottu kirjaamisen arvoiseksi, emmekä oleta vastauksia tyhjentäviksi selvityksiksi vastaajien mahdollisiksi katsomista kehyksistä.

Kestävä kehitys on aineistossa hieman ongelmallinen termi. Se sisältää taloudellisen ulottuvuuden, ja kehityksen ylipäänsä voi ajatella viittaavan kasvuun, mutta toisaalta kehitys ei edellytä taloudellista ja liiketoiminnallista kasvua ja innovatiivisuutta. Toiseksi kestävä kehitys -maininnoissa fokus vaikutti olevan toimintojen ja tuotantoprosessien kehittämisessä ympäristön kannalta kestävään suuntaan. Kestävän kehityksen mainintaa ei tässä tutkimuksessa laskettu uusien liiketoimintamahdollisuuksien esiin tuomiseksi.

Taulukossa 2 tarkastellaan aineistoa hieman eri näkökulmasta. Siinä vastauksista ei muodostu symmetristä ja keskenään yhteismitallista sarjaa vaan pikemminkin joukko toistuvia ilmiöitä, jotka ovat paikoin keskenään päällekkäisiä. Erittely ei ole tyhjentävä, ja vastauksia voisi luokitella muillakin tavoin, mutta nämä piirteet erottuivat aiheen kannalta kiinnostavina. Tarkastelu tuo esiin niin kehysten kuin vastauksissa valittujen näkökulmien ja selitysstrategioiden moninaisuuden. Tässä kohden kaikissa vastauksista tehdyissä havainnoissa ei myöskään ole suoranaisesti kyse kehystämisestä vaan pikemmin arvottavista määritelmistä.

Erityyppiset kehykset ja lähestymistavat havainnollistavat myös merkitysten muodostumisen moninaisuutta: yksi lähestyy kohdetta yhteiskunnallisena ilmiönä, toinen ideologisena tai identiteettipoliittisena kysymyksenä ja kolmas henkilökohtaisen käytännön kokemuksen kautta. Kaikki ovat tapoja määritellä, kehystää ja merkityksellistää sana tai ilmiö. Viestinnän ongelmat voivatkin toisinaan liittyä juuri kehystystapojen eroavuuteen, eivät välttämättä niinkään kehysten asiasisällöllisiin eroavaisuuksiin. Taulukossa 2 otimme huomioon vain ne vastaukset, joissa esiintyi yksi tai useampi taulukossa 1 esitetyistä kiertotalouden merkityselementeistä.

Taulukko 2. Kiertotalouden määrittelyn ja kehystämisen tapoja.

\begin{tabular}{|l|l|}
\hline Määrittely- tai kehystystapa & $\begin{array}{l}\text { Esiintymiä vastauksissa } \\
\text { (osuus kaikista vastauksista; } \\
\mathbf{n}=\mathbf{2 2 6})\end{array}$ \\
\hline Vain toiminnallinen & $63(27,9 \%)$ \\
\hline Käsitteellinen ja toiminnallinen & $38(16,8 \%)$ \\
\hline Vain käsitteellinen & $17(7,5 \%)$ \\
\hline Arvottava / subjektiivinen: positiivinen & $14(6,2 \%)$ \\
\hline Ajallinen tai historiallinen & $3(1,3 \%)$ \\
\hline Ideologinen & $3(1,3 \%)$ \\
\hline Arvottava / subjektiivinen: negatiivinen & $1(0,4 \%)$ \\
\hline
\end{tabular}


Toiminnallisella kehystyksellä tarkoitetaan tässä kiertotalouden määrittelyä konkreettisten toimintojen kautta: esimerkiksi vastauksissa mainitut roskien lajittelu, kirpputorit ja yhteisten kodinkoneiden käyttö. Toiminnallisen kehyksen käyttäjä kertoo siis tyypillisesti, mitä tehdään, kun taas käsitteellisen kehyksen käyttäjä kertoo, miksi tehdään tai mihin toiminnalla pyritään. Toiminnallinen kehys on usein semanttisesti suppeampi, koska se rajautuu kapea-alaisemmin tiettyihin toimintoihin.

Käsitteellinen kehystys tarkoittaa tässä myös lähikäsitteiden esittämistä: vastauksissa mainittiin ekologisuus, liittyy vastuullisuuteen tai liittyy kestävään kehitykseen. Käsitteelliseksi kehystykseksi luettiin myös kiertotalouden määrittely ideoiden, periaatteiden tai tavoitteiden tasolla sekä sen käsittely yhteiskunnallisena ilmiönä.

Paikoin vastauksista välittyi vaikutelma, että käsitteellinen tai terminologinen kehys oli sinänsä korrekti mutta käsitteiden tai terminologian ymmärrys oli puutteellista tai jopa olematonta, tai ainakin niiden auki kirjoittaminen oli hyvin haasteellista. Tällaisia olivat esimerkiksi talouden kierrätys -tyyppiset semanttis-loogisesti kyseenalaiset vastaukset tai esimerkin 6 vastaus, jossa esiintyy korrektia terminologiaa mutta kokonaisuus on monella tapaa virheellinen ja epälooginen. Koherentin käsitteellisen kehyksen valitseminen ei siis aina tarkoita syvällisempää semanttista ymmärrystä.

(6) Kiertotalous liittyy ilmiöön, jossa joko taloutta tehdään tuotteita kierrättämällä ja vaihtamalla keskenään tai sitten sitä tehdään kiertämällä talouden lainopillisia keinoja. Se ei kuitenkaan tarkoita samaa kuin vaihdantatalous tai harmaa talous, jotka liittyvät näihin ilmiöihin suoraan.

Vastaukset, joissa oli mukana sekä toiminnallinen että käsitteellinen ulottuvuus, indikoivat parhaimmillaan laajaa ja taiten artikuloitua ymmärrystä kohdeilmiöstä. Esimerkissä 7 tulee esiin sekä korrekti käsitteellinen kehys että esimerkinomaisesti konkreettinen toiminta. Toiminta myös kehystetään kansantalouden tasolla, mikä oli aineistossa suhteellisen harvinaista. Kaiken kaikkiaan kiertotalouden näin tiiviisti kattava ja kiteyttävä vastaus oli aineistossamme harvinaisuus.

(7) Kiertotalous tarkoittaa raaka-aineiden, hyödykkeiden yms. kierrättämistä mahdollisimman tuottavasti/taloudellisesti. Esimerkiksi käytetyn muovin uusiokäyttämistä niin, että se vaikuttaa talouteen positiivisesti. Hyödykkeen matka ei siis ala valmistamisesta ja pääty kaatopaikalle, vaan kiertää mahdollisimman tehokkaasti mahdollisimman monta kertaa. Kiertotalouden tavoitteena on ympäristöystävällinen mutta tehokas kansantalous.

Vastaajista 6,2 prosenttia ilmaisi positiivista suhtautumista kiertotaloutta kohtaan: "kiertotalous on mahtava juttu, erittäin tärkeä asia, hyvä tavoite, jota yhteiskunnassa tulisi ponnekkaasti edistää". Ajallisesti kiertotalous sijoitettiin tulevaisuuteen: "lähitulevaisuuteen liittyvä käsite, tulevaisuuden toimintaa". Vaikka kiertotalous sanana esiintyy usein politiikan kielessä ja on monelle tuttu sieltä, se ei vaikuta vastausten perusteella kovin vahvasti puoluepoliittisesti tai muuten ideologisesti värittyneeltä. Vasemmistolaisuus ja sosialismi saivat hajamainintoja. 
Vastauksista liki 48 prosenttia ei sisältänyt mitään kiertotalouden vakiintuneista merkityselementeistä (ks. taulukko 1). 38 vastausta eli lähes 17 prosenttia sen sijaan sisälsi jonkin vakiintuneista poikkeavan määritelmän, ja näistä useimmin esiintyneet on esitelty taulukossa 3. Nämä kategoriat ovat pieneltä osin päällekkäisiä, sillä samassa vastauksessa oli esimerkiksi saatettu mainita sekä raaka-aineiden kierrätys että rahan kiertäminen taloudessa. Tällaiset vastaukset on laskettu mukaan sekä taulukkoon 1 että taulukkoon 3. Näitä tapauksia oli kuitenkin verraten vähän.

Taulukossa 3 on esitetty myös tyhjien tai redundanttien vastausten määrä sekä sellaisten vastausten määrä, joissa esiintyi jokin vastaajan tietämättömyyteen viittaava ilmaus. Näissäkin saatettiin lopulta mainita jokin taulukon 1 merkityselementeistä, joten tällaiset vastaukset eivät välttämättä olleet tyhjiä tai redundantteja.

Taulukko 3. Poikkeamia vakiintuneista määritelmistä.

\begin{tabular}{|l|l|}
\hline Poikkeamat vakiintuneista määritelmistä & $\begin{array}{l}\text { Esiintymiä vastauksissa } \\
\text { (osuus kaikista vastauksista; } \\
\mathbf{n}=226)\end{array}$ \\
\hline Rahan kiertäminen taloudessa & $28(12,3 \%)$ \\
\hline Veronkierto sekä muu lakien ja sääntöjen kiertäminen & $6(2,7 \%)$ \\
\hline Vaihdantatalous, rahan käytön välttäminen & $4(1,8 \%)$ \\
\hline & \\
\hline Tyhjät ja redundantit vastaukset & $54(23,9 \%)$ \\
\hline Mainittu "en tiedä", "en ymmärrä", "en ole kuullut" tms. & $59(26,1 \%)$ \\
\hline
\end{tabular}

Muutaman kerran esiintyivät myös seuraavat selitykset: ihmisten liikkuminen alalta ja ammatista toiseen, kysynnän ja tarjonnan dynamiikka markkinoilla, talouden toimijoiden symbioottinen yhteistoiminta sekä vuoroviljely.

Rahan kiertäminen taloudessa -määritelmä palautunee monessa tapauksessa kouluajoilta tuttuun kansantalouden kiertokulku -kaavioon, esiintyyhän siinä jo otsikkotasolla sekä kierto että talous. Rahan kiertäminen mainittiin vastauksissa toisinaan myös rinnakkain materiaalien kierron tai muun kierrätyksen kanssa. Näissä kiertotalous siis hahmottui ikään kuin kattamaan kaikki monitoimijaiset kiertoprosessit yhteiskunnassa. Käsiteanalyyttisesti katsoen kiertotalous kattaa näissä vastauksissa jotakuinkin kaiken taloudellisen toiminnan yhteiskunnassa, ja sitä kautta sanan itsenäinen ilmaisuvoima hiipuu olemattomaksi. Nämäkin tapaukset on kuitenkin laskettu mukaan taulukkoon 1, mikäli niissä on mainittu jokin korrekti merkityselementti.

Kaikista vastauksista 24 prosenttia oli tyhjiä eli joko määritelmää ei annettu lainkaan tai määritelmä oli kehämäinen tai redundantti, toisin sanoen määritelmän sisältösanoina esiintyivät pelkästään kiertää ja talous jossakin muodossa (esim. jotain kiertoa taloudessa tai talouden kiertokulku). Suoranaista redundanssia esiintyi verraten 
vähän, joskin suuressa osassa esimerkiksi kierrätyksen sisältäneitä vastauksia määritelmät pohjasivat vahvasti sanoihin kierto tai talous ja sisälsivät varsin vähän näihin sanoihin itsessään liittymätöntä semanttista ainesta. Myös taulukon 1 yhteydessä mainitut semanttisesti kyseenalaiset palveluiden kierrätys -tyyppiset vastaukset vihjaavat, että taulukon 1 luvut voivat antaa jopa liian positiivisen kuvan kiertotalouden tunnettuudesta. Siksi, kokonaiskuvan valaisemiseksi, taulukkoon 3 on laskettu myös tietämättömyyttä tai epävarmuutta ilmaisseiden vastausten määrä; oikean merkityselementin sisältäneen vastauksenkin kärkenä saattoi olla "En tiedä, mutta..." -tyyppinen johdatus.

Myös vaihdantatalous-mielleyhtymä on huomion arvoinen, sillä rahatalouden supistaminen on ristiriitainen tavoite sen kanssa, että siirtymä kiertotalouteen nähdään myös kasvun ja kilpailukyvyn ajurina. Mielleyhtymä voi liittyä julkisessa keskustelussa ajoittain esitettyyn ajatukseen tuotteiden ja raaka-aineiden arvon paremmasta säilyttämisestä sekä käyttö- ja kiertoiän pidentämisestä. Tämä mielletään ehkä paluuksi vanhaan, ja tähän mahdollisesti yhdistetään myös muita menneen ajan käytänteitä, kuten vaihdantatalous.

\section{Päätelmät}

Vastaajien kiertotalous-sanalle tarjoamat määritelmät vastasivat yleisesti ottaen melko heikosti tutkimuksessa ja viranomaisviestinnässä vakiintuneita määritelmiä. Kyselyssämme vastaus tuli antaa melko nopeasti, mikä toi haastavuutta. Pidempi miettimisaika olisi mahdollisesti voinut tuottaa pidemmälle jäsenneltyjä vastauksia. Toisaalta niin sanottuun oikeaan kehykseen osuneiden vastausten määrä olisi tuskin suuresti kasvanut.

Voidaan tietenkin kysyä, onko tärkeääkään ymmärtää kiertotalous käsitteenä, mikäli sen alle sijoittuvat toimintamallit saavuttavat suosion. Kuten tämän artikkelin alussa tuotiin esiin, sanalla kiertotalous on kuitenkin huomattava rooli esimerkiksi hallitusohjelmassa ja se on siten itsessään politiikan väline. Jos sana jää ymmärtämättä tai se ei herätä positiivisia mielleyhtymiä, lankeaa varjo monen strategisen tavoitteen ja niiden viestimisen ylle.

Toisaalta voidaan pohtia, onko kiertotalous käyttökelpoinen sana kuluttajaviestinnässä tai kansalaisille suunnatussa yleistajuisessa viestinnässä, vaikka se olisi tarkoituksenmukainen kattokäsite tieteen kielessä tai työorganisaatioiden sisäisessä viestinnässä. Esimerkiksi hallitusohjelmassa kiertotaloutta ei erikseen määritellä vaan siitä puhutaan kuin yleisölle ennestään tutusta asiasta. Mikäli kansalaisen on tarkoitus ymmärtää hallitusohjelman sisältö, voidaan kohdennuksen katsoa tässä suhteessa epäonnistuneen. Hallitusohjelmassa, kuten muuallakin viranomaisviestinnässä, kiertotalouden kehys vaihtelee: Yhtäältä se on laaja ja spesifioimaton etenkin silloin, kun puhutaan Suomen kehityksen yleisistä linjoista ja toivotuista suunnista. Toisaalta vähintään implisiittisesti - kehys vaihtelee, koska sana esiintyy monessa yhteydessä: ympäristöpolitiikan yhteydessä merkitys on olennaisilta osin eri kuin vaikkapa koulutus- tai kauppapolitiikan yhteydessä. 
Kyselyymme osallistuneet samastivat kiertotalouden pääsääntöisesti kierrätykseen, joskin tämänkin yhteyden toi esiin vain noin puolet vastaajista. Koskela (2017) on tutkinut kiertotalouden käsittelyä mediassa, ja hänen havaintonsa ovat samansuuntaisia: kiertotaloudesta puhuttaessa kehystä hallitsevat kierrätys ja uudelleenkäyttö. Esimerkiksi jakamistalouden yhteydessä kiertotalous mainitaan mediassa verrattain harvoin, vaikka jakamistalouden alalla toimivista yrityksistä (kuten Uber tai Airbnb) on viime vuosina puhuttu paljon. Viranomaisten, median ja kansalaisten kehystykset eivät vaikuttaisi siis kohtaavan tehokkaan viestinnän kannalta optimaalisella tasolla. Strategiapapereiden kiertotalous on eri kuin median tai kansalaisten kiertotalous, mitä tulee sanan merkityksellistämiseen, käyttöön ja kehystykseen.

Narratiivisesta näkökulmasta asia voidaan ilmaista niin, että strategiapapereiden kiertotaloustarina ei ole saavuttanut tavoiteyleisöään (ks. Väliverronen 2007, 147-148; Lazarevic \& Valve 2017, 62). Kiertotalouden strategiseen narratiiviin kuuluu olennaisesti systeeminen eli laaja-alainen ja perustavanlaatuinen muutos. EU-tason strategioissa puhutaan kiertotalouden yhteydessä yhteiskunnallisesta transitiosta, jolla niin ikään viitataan kokonaisvaltaiseen järjestelmän ja hallitsevan ideologian muutokseen (ks. Lazarevic \& Valve 2017, 61). Tämän tutkimuksen kyselyyn vastaajat puhuvat lähes yksinomaan kuluttajien toiminnasta, eivät juurikaan instituutioiden tai yritysten eli systeemisen muutoksen varsinaisten toimijoiden ja mittarien toiminnasta. Kuluttaja on toki myös yhteiskunnallinen toimija, mutta toimijuuden paikantuminen korostetusti kuluttajatasolle voi luoda mielleyhtymiä tehottomuudesta, tunnetta suurten muutostekijöiden ja systeemisyyden puuttumisesta.

Kapea näkökulma ei suinkaan ole yksinomaan kuluttajien ongelma. Vaikka usein puhutaan painokkaasti kokonaisvaltaisesta muutoksesta, todellinen systeemitason analyysi sekä muun muassa muutoksen sosiaalisten, yhteiskunnallisten ja institutionaalisten näkökulmien käsittely ovat Kirchherrin ja muiden $(2017,227)$ sekä Merlin ja muiden $(2018,712)$ mukaan jääneet tieteellisessä tutkimuksessakin marginaaliseen asemaan. Myös Murray ja muut $(2017,376)$ ovat kiinnittäneet huomiota huomattavaan teknis-luonnontieteelliseen painotukseen ja kokonaisvaltaisen yhteiskunnallisen analyysin vähyyteen kiertotaloutta käsittelevässä tutkimuksessa.

Samoin liiketoiminnallinen kehyselementti, joka strategiapuheessa on olennainen, puuttuu lähes tyystin kyselyymme osallistuneiden vastauksista. Tässäkin yhteinen kieli tai kehys näyttäisi puuttuvan: se mikä yhdelle on kilpailukyvyn ja talouskasvun ajuri ja läpäisevä strateginen perusta, näyttäytyy toiselle yksinomaan kierrätyksenä ja uudelleenkäyttönä, ilman erityistä liiketaloudellista innovatiivisuutta. Lazarevic ja Valve $(2017,63)$ tuovat esiin EU:n tuottamasta kiertotalousnarratiivista siihen ladatut suuret odotukset sekä vahvan me-toimijuuden, uskon yhteiseen ponnistukseen menestyksen eteen. Tällaisten odotusten toteutuminen edellyttäisi vahvaa yhtenäistä näkemystä yhteiskunnassa, mitä tämän tutkimuksen tulokset eivät varsinaisesti tue. Samansuuntaisiin tuloksiin päätyivät Repo ja muut (2018, 261-262) vertaillessaan Euroopan valtioiden politiikkaohjelmia ja kansalaisten tulevaisuusnäkemyksiä: valtiotason strategiapuhe on jäänyt etäiseksi ja kiertotalous käsitteenä epämääräiseksi. 
Voidaan myös pohtia, onko tietynlainen, etenkin uhkien, riskien ja haasteiden määrittelemä kehys niin vakiintunut median ympäristö- ja ilmastojutuissa, että positiivisen kasvun, hyvinvoinnin ja menestyksen näkökulmat tuntuvat intuitiivisesti vierailta (ks. Kangas 2016, 219-221). Dramaattinen uhka ja kuluttajiin kohdistuva toimintapaine edellä rakennetut mediatekstit saattavat helposti herättää vastarintaa, toivottomuutta ja kyllästymistä. Näkökulmaa voisi laajentaa esimerkiksi nostamalla näkyvämmin esiin monin paikoin pitkälle vietyä kehitystyötä tai kiertotalouden periaatteilla menestyneitä yrityksiä.

Kiertotalous tarjoaa tuttuina elementteinä sanat kierto ja talous, ja näiden avulla moni tutkimukseemme vastanneista rakensi semanttisia kehyksiä. Nämä tutut elementit ovat kuitenkin semanttisesti todella laajoja ja monikäyttöisiä, joten monessa tapauksessa myös kehykset jäävät varsin laajoiksi ja epämääräisiksi. Kiertotalous on sanasemanttisesti ja rakenteellisesti konstruktio, joka mahdollistaa varsin monenlaiset tulkinnat ilman, että sanaa itselleen selittävä tulkitsija kokisi semanttista riitasointisuutta. Kielitoimiston sanakirjan toimittaja Liisa Nuutinen (2014) kritisoi jo vuosia sitten sanaa kiertotalous hämäryydestä ja monitulkintaisuudesta ja toisaalta ennakoi osuvasti, että sana tästä huolimatta todennäköisesti jää elämään.

Kierron ja talouden edellä kuvattu laajuus heijastui aineistossamme myös semanttisesti väljissä vastauksissa, joissa puhuttiin esimerkiksi tavaroiden kierrättämisestä käyttäjältä toiselle. Jos pelkästään se, että tavaralla on useampi käyttäjä sen elinkaaren aikana, mielletään kiertotaloudeksi, laajenee kiertotalous-sanan semantiikka valtavasti. Siten myös sen hahmottaminen, ymmärtäminen ja käyttö voivat tuottaa vaikeuksia valistuneillekin kielenpuhujille. Jos taas edellä mainittu tilanne on kiertotaloutta vain tietyin ehdoin, edellyttää kiertotalouden semantiikan koherentti hahmottaminen suhteellisen spesifiä kehystietoa. Tässä mielessä voidaan ajatella, että kiertotaloussanan ilmaisuvoimaa ja käyttökelpoisuutta uhkaavat sekä hahmoton laajuus että spesifin asiantuntijatiedon vaatimus.

Vastauksissa kiertotalous samastettiin vahvasti kierrätykseen. Vastauksen osuminen vain yhteen tai muutamaan kiertotalouden aspektiin oli toki odotuksenmukaista, koska käsite on laaja ja tutkimuslomakkeen kysymys kutsui nimenomaan mielikuvia ja mielleyhtymiä. Kiertotaloudesta puhutaan monenlaisissa yhteyksissä, ja eri alojen asiantuntijat nostavat usein esiin vain yhden näkökulman aiheeseen. Tätä kautta kuulijalle voi jäädä mieleen nimenomaan jokin tietty kehys, jota voi olla vaikea vaihtaa tai laajentaa. Totunnaiset kehykset, kuten jätteiden hallinnointi ja kierrätys, selittävät kiertotaloutta vain osittain mutta ovat kuitenkin siinä määrin vakiintuneita rakenteita, että tulkinnan laajentaminen on haastavaa. Kiertotalous laajasti ymmärrettynä edellyttäisi kokonaan uuden, tuttuja kehyksiä laajemman semanttisen kehyksen omaksumista.

Vastauksissa tuli esiin myös kehystystapojen moninaisuus puhujan perspektiivin suhteen. Paikoin kiertotaloutta selitettiin osana käsiteverkostoa, mutta useammin käytetty kehys oli toiminnallinen eli toimintoihin ja käytäntöihin kiinnittyvä. Tällöin selitystapa on usein anekdotaalinen eli keskeiseksi nousee jokin yksityiskohta tai mielleyhtymä (ks. Diederich 2015, 122-123; Fillmore 1982; 1985). Tämä ilmeni muun muassa siten, että kiertotalous kehystettiin usein kotitalouden toimintoihin esimerkiksi kan- 
santalouden tai muun laajemman kontekstin sijaan. Näkökulma oli siis kuluttajan valinnoissa, ei esimerkiksi yritysten tai julkisten organisaatioiden toiminnassa saati systeemisissä ratkaisuissa.

Tämä on ymmärrettävää laajan ja vaikeasti hahmotettavan käsitteen yhteydessä. Kiertotalouden systeeminen ulottuvuus sekä kestävää kehitystä liiketoiminnalliseen innovatiivisuuteen yhdistävä talousmalliajattelu jäivät tällä tavoin kuitenkin verrattain pieneen rooliin. Samoin kiertotalouden muut toiminnalliset ulottuvuudet kuin kierrätys jäivät vähälle huomiolle, vaikka esimerkiksi jakamis- ja vuorokäyttöpalvelut ovat olennainen osa kiertotalouden liiketoimintaulottuvuutta. Jos kiertotalous-sana ei herätä mielikuvia talousmallin muutoksesta ja liiketoiminnallisista menestysmahdollisuuksista, voiko käsitteeseen vahvasti nojaava poliittinen retoriikka olla tehokasta? Tässä piilee kenties yksi huomionarvoinen linja kiertotalousviestinnän kehittämisessä.

\section{Kirjallisuus}

Blomsma, Fenna \& Brennan, Geraldine (2017). The Emergence of circular economy. A new framing around prolonging resource productivity. Journal of Industrial Ecology 21:3, 603-614. https://doi.org/10.1111/jiec.12603

Coulson, Seana (2001). Semantic Leaps: Frame-Shifting and Conceptual Blending in Meaning Construction. Cambridge: Cambridge University Press. https://doi.org/10.1017/CBO9780511551352

Coulson, Seana (2015). Frame-shifting and frame semantics: joke comprehension on the space structuring model. Teoksessa: Brâne, Geert; Feyaerts, Kurt \& Veale, Tony (toim.). Cognitive Linguistics and Humor Research. Berlin: De Gruyter, 167-19o. https://doi.org/10.1515/9783110346343-009

Diederich, Catherine (2015). Sensory adjectives in the Discourse of Food: A Frame-Semantic Approach to Language and Perception. Amsterdam: John Benjamins. https://doi.org/10.1075/celcr.16

Edwards, Derek (1997). Discourse and cognition. London: Sage.

Entman, Robert M. (2004) Projections of Power: Framing news, public opinion, and U.S. foreign policy. Chicago, IL: University of Chicago Press. https://doi.org/10.7208/chicago/9780226210735.001.0001

Entman, Robert M. (2007). Framing bias: Media in the distribution of power. Journal of Communication 57:1, 163-173. https://doi.org/10.1111/j.146o-2466.2006.00336.x

Euroopan parlamentti (2018). Mitä kiertotalous on ja miksi sillä on merkitystä? Saatavilla: https://www. europarl.europa.eu/news/fi/headlines/economy/20151201ST005603/mita-kiertotalous-on-ja-miksisilla-on-merkitysta (luettu 6.9.2019).

Evans, Vyvyan. (2009). How Words Mean: Lexical Concepts, Cognitive Models, and Meaning Construction. Oxford University Press. https://doi.org/10.1093/acprof:0so/9780199234660.003.0007

Fillmore, Charles J. (1982). Frame semantics. Teoksessa: The Linguistic Society of Korea (toim.). Linguistics in the Morning Calm. Seoul: Hanshin Publishing, 111-137.

Fillmore, Charles J. (1985). Frames and the semantics of understanding. Quaderni di Semantica 6:2, 222-254.

Fillmore, Charles J. \& Baker, Collin (2009). A frames approach to semantic analysis. Teoksessa: Heine, Bernd; Narrog, Heiko (toim.). The Oxford Handbook of Linguistic Analysis. Oxford University Press, 791-816. https://doi.org/10.1093/oxfordhb/9780199544004.013.0013

Gawron, Jean-Mark (2019). Frame semantics. Teoksessa: Maienborn, Claudia; Heusinger, Klaus \& Portner, Paul (toim.). Semantics - theories. Berlin: De Gruyter, 57-85. https://doi.org/10.1515/9783110589245-003

Gamerschlag, Thomas; Gerland, Doris; Osswald, Rainer \& Petersen, Wiebke (2014). General introduction. Teoksessa: Gamerschlag, Thomas; Gerland, Doris; Osswald, Rainer \& Petersen, Wiebke (toim.). Frames and Concept Types: Applications in Language and Philosophy. Cham: Springer, 3-21. https://doi.org/10.1007/978-3-319-01541-5_1 
Geissdoerfer, Martin; Savaget, Paulo; Bocken, Nancy M.P. \& Hultink, Erik Jan (2017). The Circular economy A new sustainability paradigm? Journal of Cleaner Production 143:1, 757-768. https://doi.org/10.1016/j.jclepro.2016.12.048

Goffmann, Erving (1974). Frame Analysis: An Essay on the Organization of Experience. London: Harper and Row.

Genovese, Andrea; Acquaye, Adolf A.; Figueroa, Alejandro \& Koh, S. C. Lenny (2017). Sustainable supply chain management and the transition towards a circular economy: Evidence and some applications. Omega 66 (part B), 344-357. https://doi.org/10.1016/j.omega.2015.05.015

Halliday, Michael A.K. \& Matthiessen, Christian M.I.M. (2014). Halliday's Introduction to Functional Grammar. Revised by Christian M.I.M. Matthiessen. London: Routledge.

Harju, Aki \& Karvonen, Erkki (2016). Lipeä yllätti Talvivaaran: Onnettomuuden narratiivi ja onnettomuuskehys kaivoskirjoittelussa. Media Q viestintä 39:3, 184-208. https://doi.org/10.23983/mv.61420

Hirvonen, Jukka \& Vanhatalo, Maaria (2018). Ympäristöasenteet ja kaupunkikehitys Helsingissä ja Vantaalla. Tutkimuksia 2018:1. Helsingin kaupunki, kaupunginkanslia, kaupunkitutkimus ja -tilastot.

Homrich, Aline Sacchi; Galvão, Graziela; Gamboa Abadia, Lorena \& Carvalho, Marly M. (2017). The Circular economy umbrella: Trends and gaps on integrating pathways. Journal of Cleaner Production 175, 525543. https://doi.org/10.1016/j.jclepro.2017.11.064

Joutsenvirta, Maria (2006). Ympäristökeskustelun yhteiset arvot: diskurssianalyysi Enson ja Greenpeacen ympäristökirjoituksista. Acta Universitatis oeconomicae Helsingiensis A273. Aalto-yliopiston kauppakorkeakoulu, Helsinki.

Kangas, Jarkko (2016). Näkymätön ilmasto, näkyviä kuvia: Ilmastoriskin visualisointi ja kuvallinen kehystäminen Helsingin Sanomissa. Media Q viestintä 39:4, 209-227. https://doi.org/10.23983/mv.61407

Karvonen, Erkki (2000). Tulkintakehys (frame) ja kehystäminen. Media Q viestintä 23:2, 78-84. Saatavilla: https://journal.fi/mediaviestinta/article/view/61529 (luettu 29.5.2020).

Kirchherr, Julian; Reike, Denise \& Hekkert, Marko (2017). Conceptualizing the circular economy: An analysis of 114 definitions. Resources, Conservation and Recycling 127, 221-232. https://doi.org/10.1016/j.resconrec.2017.09.005

Kauppalehti.fi (23.8.2019). H\&M aikoo pelastaa kivijalkakaupat kiertotaloudella - perustaa vuokrauspalvelun ja ompelimon. Saatavilla: https://www.kauppalehti.fi/uutiset/hm-aikoo-pelastaa-kivijalkakaupatkiertotaloudella-perustaa-vuokrauspalvelun-ja-ompelimon/a7fba42b-4705-4704-8beo-f77e6416cgbf (luettu 5.2.2020).

Korhonen, Jouni; Honkasalo, Antero \& Seppälä, Jyri (2018). Circular economy: The concept and its limitations. Ecological Economics 143, 37-46. https://doi.org/10.1016/j.ecolecon.2017.06.041

Koskela, Juliana (2017). Circular economy definitions and assessment in Finnish media. Master's thesis. Jyväskylä University School of Business and Economics. Saatavilla: https://jyx.jyu.fi/bitstream/ handle/123456789/58214/URN\%3aNBN\%3afi\%3ajyu-201805292889.pdf?sequence=1\&isAllowed=y\#p age39 (luettu 5.2.2020).

Lazarevic, David \& Valve, Helena (2017). Narrating expectations for the circular economy: Towards a common and contested European transition. Energy Research Q Social Science 31, 60-69. https://doi.org/10.1016/j.erss.2017.05.006

Mahanty, Sampriti; Boons, Frank; Handl, Julia \& Batista-Navarro, Riza Theresa (2019). Understanding the evolution of circular economy through language change. Proceedings of the 1st international workshop on computational approaches to historical language change, 250-253. https://doi.org/10.18653/v1/W19-4731

Malrieu, Jean Pierre (1999). Evaluative Semantics. Cognition, language and ideology. London: Routledge.

Matthes, Jörg (2009). What's in a frame? A content analysis of media framing studies in the world's leading communication journals, 1990-2005. Journalism Q Mass Communication Quarterly 86:2, 349-367. https://doi.org/10.1177/107769900908600206

Merli, Roberto; Preziosi, Michele; Acampora, Alessia (2018). How do scholars approach the circular economy? A systematic literature review. Journal of Cleaner Production 178, 703-722. https://doi.org/10.1016/j.jclepro.2017.12.112

Murray, Alan; Skene, Keith \& Haynes, Kathryn (2017). The circular economy: An interdisciplinary exploration of the concept and application in a global context. Journal of Business Ethics 140:3, 369-380. https:// doi.org/10.1007/s10551-015-2693-2

Niemi, Jarkko (2013). Tiedon rajat ja vuorovaikutus. Toteamukseen tai vaihtoehtokysymykseen vastaavat VOI OLLA -rakenteet. Virittäjä 117:2, 201-241. 
Nuutinen, Liisa (2014). Kierrätystä kiertotaloudessa. Kielikello. Kielenhuollon tiedotuslehti 3/2014. Helsinki: Kotimaisten kielten keskus.

Nylén, Erkki-Jussi (2019). Kiertotaloussiirtymä ja uudet markkinat - Kahden kiertotalousraportin argumenttianalyysi. Alue ja ympäristö 48:1, 14-28. https://doi.org/10.30663/ay.77836

Osallistava ja osaava Suomi - sosiaalisesti, taloudellisesti ja ekologisesti kestävä yhteiskunta (2019). Pääministeri Antti Rinteen hallituksen ohjelma 6.6.2019. Valtioneuvoston julkaisuja 2019:23. Helsinki.

Pentzold, Christian; Sommer, Vivien; Meier, Stefan \& Fraas, Claudia (2016). Reconstructing media frames in multimodal discourse: The John/Ivan Demjanjuk trial. Discourse, Context Q Media 12, 32-39. https://doi.org/10.1016/j.dcm.2016.03.001

Reike, Denise; Vermeulen, Walter J.V. \& Witjes, Sjors (2018). The circular economy: New or refurbished as CE 3.0? - Exploring controversies in the conceptualization of the circular economy through a focus on history and resource value retention options. Resources, Conservation and Recycling 135, 246-264. https://doi.org/10.1016/j.resconrec.2017.08.027

Repo, Petteri; Anttonen, Markku; Mykkänen, Juri \& Lammi, Minna (2018). Lack of congruence between European citizen perspectives and policies on circular economy. European Journal of Sustainable Development 7:1, 249-264. https://doi.org/10.14207/ejsd.2018.v7n1p249

Rönkä, Anu-Liisa (2011). Matkapuhelinsäteily mediassa - Terveysriskikeskustelun kehysanalyysi. Media Q viestintä 34:2, 20-43. https://doi.org/10.23983/mv.62913

Sauvé, Sebastien; Bernard, Sophie \& Sloan, Pamela (2016). Environmental sciences, sustainable development and circular economy: Alternative concepts for trans-disciplinary research. Environmental Development 17, 48-56. https://doi.org/10.1016/j.envdev.2015.09.002

Singh, Jagdeep \& Ordonez, Isabel (2016). Resource recovery from post-consumer waste: important lessons for the upcoming circular economy. Journal of Cleaner Production 134 Part A, 352-353. https://doi.org/10.1016/j.jclepro.2015.12.020

Sitra Q Kantar TNS (2017). Resurssiviisas kansalainen. Helsinki: Sitra, Suomen itsenäisyyden juhlarahasto.

Sitra (2016). Mitä nämä käsitteet tarkoittavat? Kiertotalouden tiekartta Suomelle 2016-2025. Helsinki: Sitra, Suomen itsenäisyyden juhlarahasto. Saatavilla: https://www.sitra.fi/artikkelit/mita-nama-kasitteettarkoittavat/ (luettu 6.9.2019).

Suomen Kuvalehti (29.8.2019). Vaatejätti H\&M avaa vuokrauspalvelun - Viherpesua, tyrmää asiantuntija: aito muutos vaatisi tuotannon ja mallistojen vähentämistä. Saatavilla: https://suomenkuvalehti.fi/ jutut/kotimaa/talous/vaatejatti-hm-avaa-vuokrauspalvelun-viherpesua-tyrmaa-asiantuntija-aitomuutos-vaatisi-tuotannon-ja-mallistojen-vahentamista/ (luettu 5.2.2020).

Stoddard, Mark C.J. \& Smith, Jillian (2016). The Endangered Arctic, the Arctic as resource frontier: Canadian news media narratives of climate change and the North. Canadian Review of Sociology 53:3, 316-336. https://doi.org/10.1111/cars.12111

Torelli, Riccardo; Balluchi, Federica \& Lazzini, Arianna (2019). Greenwashing and environmental communication: Effects on stakeholders' perceptions. Business Strategy and the Environment August 2019, 1-15. https://doi.org/10.2139/ssrn.3470659

Tromble, Rebekah \& Meffert, Michael (2016). The life and death of frames: Dynamics of media frame duration. International Journal of Communication 10, 5079-5101.

Verloo, Mieke \& Lombardo, Emanuela (2007). Contested gender equality and policy variety in Europe: Introducing a critical frame analysis approach. Teoksessa: Verloo, Mieke (toim.). Multiple Meanings of Gender Equality. A Critical Frame Analysis of Gender Policies in Europe. Budapest: Central European University Press, 21-50.

Väliverronen, Esa (1996). Ympäristöuhkan anatomia. Tampere: Vastapaino.

Väliverronen, Esa (2007). Geenipuheen lupaus - Biotekniikan tarinat mediassa. Viestinnän julkaisuja 13. Viestinnän laitos. Helsingin yliopisto.

Watson, James (2016). Media Communication: An Introduction to Theory and Process. Basingstoke: Palgrave Macmillan.

Wolsko, Christopher; Ariceaga, Hector \& Seiden, Jesse (2016). Red, white, and blue enough to be green: Effects of moral framing on climate change attitudes and conservation behaviors. Journal of Experimental Social Psychology 65, 719. https://doi.org/10.1016/j.jesp.2016.02.005 